UDC 697.329+662.997:696.48

V.O. Dubkovsky, DEng, Prof., V.P. Kravchenko, DEng, Prof., J.V. Kravchenko, Master

Odessa National Polytechnic University, 1 Shevchenko Ave., 65044 Odessa, Ukraine; e-mail: vpkrav@rambler.ru

\title{
METHODS OF ACCOUNTING THE HOT WATER CONSUMPTION MODES AT THE SOLAR INSTALLATIONS DESIGN
}

В.О. Дубковський, В.П. Кравченко, С.В. Кравченко. Методика обліку режиму споживання гарячої води при проектуванні сонячних установок. Розглянуто особливості сонячних установок гарячого водопостачання великої потужності. Метою дослідження $\epsilon$ розробка методики обліку добового режиму споживання гарячої води, що визначає динамічні характеристики сонячної установки. Проаналізовано основні схеми сонячних установок і показано їх недоліки з точки зору задоволення потреб. Для поліпшення динамічних характеристик установки запропоновано використання бака оперативної витрати з вбудованим теплообмінником, через який проходить весь теплоносій 3 сонячних колекторів перед швидкісним теплообмінником, що нагріває акумулюючу ємність. Науковою новизною $є$ доведення того, що основною характеристикою цього баку є не об'єм, а потужність вбудованого теплообмінника, яка в свою чергу визначається сумарною тепловою потужністю поля сонячного колектора. Як екологічну складову експлуатаційних витрат запропоновано враховувати плату за викиди продуктів згоряння. Як практичне використання методики приводиться приклад оптимізації потужності сонячного колектору для комунального підприємства.

Ключові слова: сонячна установка, водопостачання, сонячний колектор.

V.O. Dubkovsky, V.P. Kravchenko, J.V. Kravchenko. Methods of accounting the hot water consumption modes at the solar installations design. Peculiarities of the high-powered solar systems for hot water heating are considered. The purpose of work consists in development of methods for accounting the 24-hourly hot water consumption mode, determining the solar systems dynamic descriptions. The basic solar system schemes are analyzed with their shortages from the user satisfaction view point due to sun energy. For the dynamic parameters improvement the use of operative expense tank is examined such receptacle bearing built-in worm-pipe, through which all heat carrier from solar collectors passes before entering the fast heat exchanger which heats a tank-accumulator. The scientific novelty refers to the proof that this tank principal parameter is a not the volume, but the built-in exchanger capacity, determined by the solar collectors field total thermal power. As an ecological constituent of operating costs it is suggested to take into account cost paid for the emission of combustion products. As this method practical application example considered is the solar collectors capacity optimization for a communal enterprise.

Keywords: solar installation, water-supply, solar collector.

Introduction. The solar installations for hot water supply are becoming more widely used nowadays $[1,2]$. A continued growth in energy prices attracts more attention to the possible use of such a stable and environmentally friendly energy source, as the sun, including in the domestic sector. The main disadvantage of solar systems (SS) is their high cost. However, many enterprises prefer to install SS considering their sufficiently high capacity, a number of features characterizing the individual installations. Thus still actual is the issue of maximizing the existing SS effectiveness, as well as reducing the impact of negative factors such as high inertia and bad dynamic characteristics. Using dualmode systems (two energy sources used: sun and conventional fuels) does smoother out the disadvantages of solely SS installing.

Analysis of recent research and publications. If the individual SS are operating the domestic hot water (DHW) cylinders, peculiarities of the large power plants design provide the availability of the hot water high-capacity storage tank i.e., the DHW is replaced by a fast heat exchanger and a storage tank, that being ultimately cheaper. The hot water storage volume must comply with a daily or a greater need.

DOI 10.15276/opu.2.46.2015.18

(C) 2015 The Authors. This is an open access article under the CC BY license (http://creativecommons.org/licenses/by/4.0/). 
Fig. 1 [3] represents a high-capacity SS diagram. Analyzing the dynamic characteristics of this structure we observe that the incoming to the accumulator hot water is mixed with cold water in the tank. At this it takes long to reach a predetermined value of the resulting temperature. Consumers get the desired temperature water only after draining large water amounts into the sewer. The water heated in the heat exchanger will be supplied to the storage only when the consumption for accumulating capacity begins. The collectors' connection scheme also seems inappropriate one. The working fluid is heated consistently in all series' reservoirs, reaching significant temperatures, at maximum heat loss to the environment. In terms of the dynamic characteristics such a scheme is the least convenient.

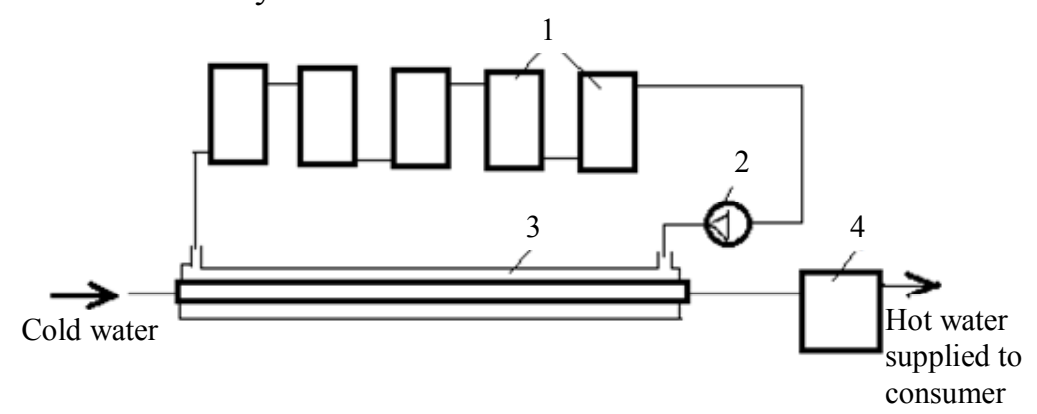

Fig. 1. Diagram of the hot water supply solar installation of high capacity: 1 - solar collectors; 2 - pump; 3 - heat exchanger; 4 - storage tank

Main manufacturers of SS equipment Viessmann Werke and Buderus [4, 5] engage a different scheme (Fig. 2). The collectors' rows of and the collectors in those series are connected in parallel, that reduces the heat loss to the environment.

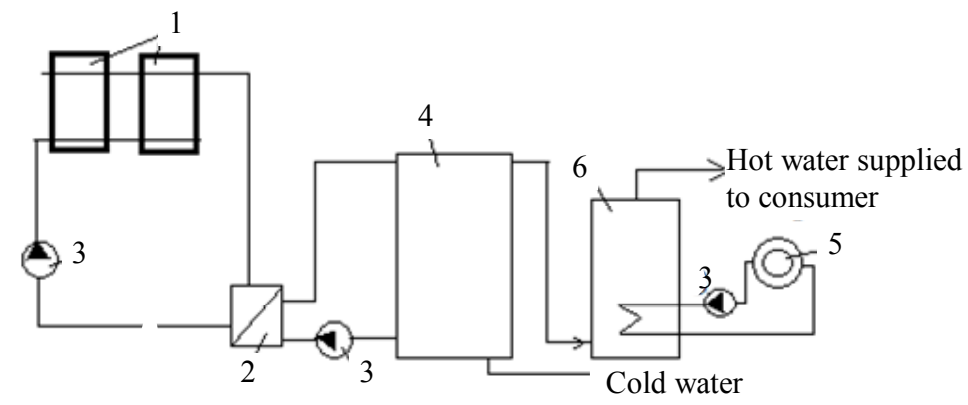

Fig.2. Diagram of high capacity SS bivalent installation: 1 - solar collectors; 2 - fast heat-exchanger; 3 - pump; 4 - storage tank; 5-boiler; 6-capacitive water heater

Initially, the cold water is heated by the sun which energy is received by the heat transfer medium, ensuring minimal losses. Two tanks 4 and 6 provide sufficient volume for hot water storage. This scheme disadvantage relates to neglecting the water consumption regime, i.e., in the morning when most consumers already starts work (canteens, child care centers, etc.), there is no hot water reserve in the accumulator 4 , fed by the solar installation. While the large capacity 4 is heated, the consumer gets the boiler-heated water.

Thus, the existing SS schemes do not provide the periodically changing needs. Changes in consumption mode are recovered with an additional installation (boiler). The reference sources $[4,5]$ indicate the need to consider the mode of consumption when designing, never specifying the way of this factor accounting.

The Aim of the Research. The studied object represents the diagram of high-capacity solar systems for hot water supply.

The aim is to develop a SS scheme, providing the needs with the account to the consumption mode, as well as the methods of such a scheme feasibility estimation.

To achieve the aim the following tasks are formulated: 
- Designing a SS scheme capable of immediately providing the consumer with hot water with a maximum contribution of solar energy;

- Developing a methodology for calculating the system's various elements capacity to ensure the consumption needs at different time 24-hourly.

Main Body.

Development of the system, taking into account the consumption mode. To solve the problem of consumer needsэ dynamic provision, the sources [6] proposed to use the operating expenses tank (OET) (Fig. 3) having essentially smaller volume than the accumulating tank or buffering capacity. The SS heated carrier passes first through the OET and heats the water there, and then is fed to the main storage tank. So the water heating for consumers is accelerated. Moreover, no additional controllers are required. The higher temperature of the heated water in OET is, the higher temperature has the heat transfer fluid exiting from OET, and the greater is the energy amount transferred to the storage tank.

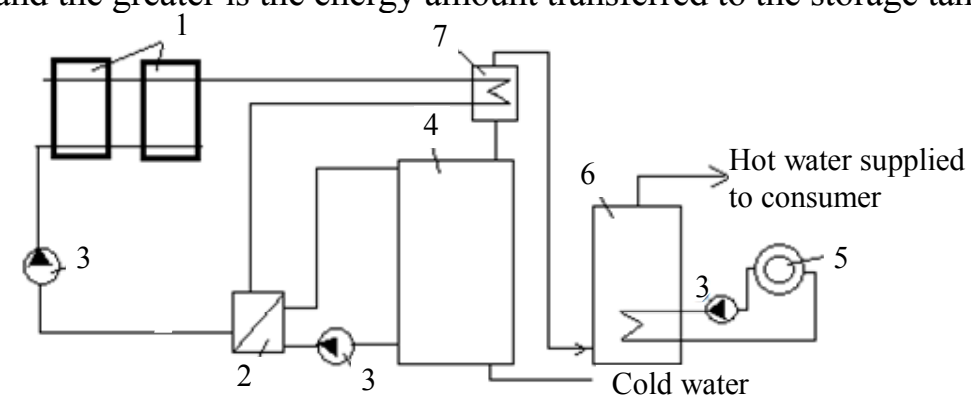

Fig. 3. Diagram of SS with a higher dynamic characteristic: 1 - solar collectors; 2 - fast heat-exchanges;

3-pump; 4-tank batteries; 5-boiler; 6-capacitive water heater; 7 -operating expenses tank

Now the question arises how to link the required OET capacity with the mode of hot water consumption.

Calculation of the operating expenses tank. The main storage tank volume covers the daily water needs. The OET should provide every isolated need for a day.

To solve the formulated problem we compose a system of equations:

1. OET thermal capacity:

$$
Q_{O E T}=k F_{O E T} \Delta t_{O E T}^{H C-H W},
$$

where $k$ - heat transfer coefficient;

$F_{O E T}$ - area of the heat exchanger in the OET;

$\Delta t_{O E T}^{H C-H W}-$ mean log temperature difference between heat carrier and heated water in the OET.

2. Time of water heating in the OET

$$
t=\frac{V_{O E T} c_{p} \Delta t^{H-C}}{Q_{O E T}},
$$

where $V_{O E T}-$ OET capacity, 1 ; at relatively low temperatures, equivalent to the mass of water in the tank, $\mathrm{kg}$

$\Delta t^{H-C}$ - temperature drop showing the value at which water is heated in the OET.

3. The time needed to ensure the consumer needs:

$$
t_{1}=\frac{V_{1}}{V_{O E T}} t,
$$

where $V_{1}$ - amount of water needed for the user during the time $t_{1}$ (set by the user).

Solving the resulting system obtained is the equation

$$
\frac{t_{1} V_{O E T}}{V_{1}}=\frac{V_{O E T} c_{p} \Delta t^{H-C}}{Q_{O E T}},
$$


which shows that the consumer's need provision is not determined by the volume of OET (which decreases), but when the relation below is satisfied:

i.e. depends onto OET thermal capacity.

$$
\frac{t_{1}}{V_{1}}=\frac{c_{p} \Delta t^{H-C}}{Q_{O E T}}
$$

In order to ensure a predetermined hot water consumption when $i$-th mode of consumption $G_{i}$ the OET required thermal capacity is

$$
Q_{O E T, i}=G_{i} c_{p} \Delta t^{H-C}=G_{H C} c_{p, H C} \Delta t_{H C}=k F_{O E T}\left(t_{H C}-t_{H W}\right),
$$

where $G_{i}$ - consumption of hot water for the $i$-th period of consumption.

As can be seen, the OET heat capacity is determined by the heat carrier flow rate which heating which in turn is provided by solar collectors. In other words, the OET capacity depends onto SS capacity

Algorithm for accounting the consumption mode:

- Determining the required SS capacity for each consumption period:

$$
Q_{S S, i}=G_{i} c_{p} \Delta t^{H-C} .
$$

- Now we determine the area and the amount of solar collectors (SC) that meet the $i$-th consumption period needs. When $\Delta t^{H-C}=20^{\circ} \mathrm{C}$ the water flow for each period will be

$$
G_{i}^{H-C}=\frac{Q_{O E T, i}}{c_{p} \Delta t^{H-C}}=\frac{1}{4,19 \cdot 20} Q_{O E T, i} .
$$

— Taking into account the adopted specific coolant flow per $1 \mathrm{~m}^{2} \mathrm{SC}\left(\tilde{V}=(30 \ldots 50) 1 /\left(\mathrm{m}^{2} \cdot h\right)\right)$, the area and the number of SC are

$$
F_{S C, i}=\frac{G_{i}^{H-C}}{\tilde{V}} ; \quad N=\frac{F_{S C, i}}{f_{i}},
$$

where $f_{i}$ - area of one SC.

All needs are covered at the highest of the calculated capacity values

Thus, to ensure the required amounts, an adequate solar installation capacity, i.e. SC area, is required as well as the corresponding heat exchanger capacity in the OET (heat transfer area). In general case, the operating expenses tank can be replaced with a fast heat exchanger, which is often cheaper.

Optimization of the required solar installation capacity to meet the daily needs. The hot water supply system with SS should necessarily have an additional source of heat (often a gas boiler). When insufficient heating with SS the water is reheated with the boiler, i.e. lack of SS dynamic characteristics is offset by costs of fossil fuels. As explained above, the increase in SS dynamic characteristics is carried through its increased capacity, which leads to an increase in its value.

Results. Consider the optimization techniques on the example of the holiday camp canteen, supposing the needs of 500 campers and 50 staff members. According to the Building code (SNiP) 02.04.01-85 one dish requires 41 of hot water.

Let us assume the following distribution of consumption:

- Breakfast (1 meal): 550 pers. $\times 41=22001$;

- Lunch (2 meals): 550 pers. $\times 2$ meals $\times 41=44001$;

- Dinner (1 meal): 550 pers. $\times 41=22001$.

The breakfast period lasts 3 hours (including cooking meals and cleaning), lunch -4 hours, dinner -3 hours.

SS thermal capacity for the $i$-th period

$$
Q_{1}=Q_{3}=\frac{2200 \cdot 4,19 \cdot(55-15)}{3 \cdot 3600}=34,141 \mathrm{~kW},
$$




$$
Q_{2}=\frac{4400 \cdot 4,19 \cdot(55-15)}{4 \cdot 3600}=51,21 \mathrm{~kW} .
$$

Calculation excluding consumption dynamics:

- The desired amount of water

$$
2200+4400+2200=88001 \text { per day; }
$$

- SC capacity

$$
Q_{S C}=\frac{8800 \cdot 4,19 \cdot(55-15)}{12 \cdot 3600}=34,141 \mathrm{~kW} .
$$

We proceed to an economical comparison of the two available options (with and without consumption mode): ural gas;

- SC capacity of $34,141 \mathrm{~kW}$ - lack of power during the preparation of lunch is covered by nat-

- SC capacity of $51,21 \mathrm{~kW}$ covers the consumption dynamics.

The comparison is based on annual reduced costs:

$$
R C_{A}=(p-a) C I+O C_{A},
$$

where $C I$ - capital investments (units cost);

$p$ - standard rate of payback, accepted value of 0,06 ;

$a$ - coefficient taking into account the cost of repairs, adopted value of 0,05 ;

$O C_{A}$ - annual operating costs that include the costs of fuel and charges for emissions during combustion.

A more powerful unit has not only more quantity of solar collectors, but also more expensive manifold because of its larger diameter, more expensive expansion tank, etc.

Number of solar collectors for the $1^{\text {st }}$ and $2^{\text {nd }}$ cases

$$
N_{1}=\frac{Q_{1}}{\tilde{q} f_{i}}=\frac{34,141}{0,5 \cdot 2,04} \approx 34 ; N_{2}=\frac{51,21}{0,5 \cdot 2,04} \approx 51,
$$

where $\tilde{q}$ - average useful power density of solar radiation, adopted value of $0,5 \mathrm{~kW} / \mathrm{m}^{2}$ [4];

$f_{i}$ - area of one SC, adopted value of $2,04 \mathrm{~m}^{2}$.

Let we estimate the number of times increase/decrease in the solar installation value, especially considering the mode of consumption.

Analysis of SS equipment calculation showed that its cost makes six times the value of the SC. At a cost of 3059 UAH per collector, the SS with 33 collectors cost is $605682 \mathrm{UAH}$; SS with 50 collectors - $917700 \mathrm{UAH}$.

Thus, the change in SS value when increased capacity leads to increased installation costs by 51,5\%.

The difference in supplied amount of heat

$$
\Delta Q=(50-33) \cdot 4 \cdot 3600=244800 \mathrm{~kJ} .
$$

This corresponds to a natural gas consumption of $7,77 \mathrm{~m}^{3}$ per day.

Annual reduced costs given for these options considering the price of natural gas as $5966 \mathrm{UAH}$ per $1000 \mathrm{~m}^{3}$, and fees for $\mathrm{CO}_{2}$ emissions of $0,24 \mathrm{UAH} / \mathrm{t}$ (when burning $1 \mathrm{~m}^{3}$ of natural gas released is $1,966 \mathrm{~kg}$ of $\mathrm{CO}_{2}$ ) are $R C_{A}^{1}=222467$ and $R C_{A}^{2}=100947 \mathrm{UAH}$, properly.

Thus, the SS, which fully meets requirement of all the consumption modes is, cheaper than a SS, designed without taking into account this factor. It should be pointed out that an important role here is attributed to the equipment prices and natural gas cost.

Conclusions. An efficient schedule of consumers hot water supply can be provided using the operating expenses tank. The dynamic characteristics are not determined by volume, but by the OET heat exchanger capacity (in practice it is a capacitive heater). In turn, the OET capacity is determined by 
the area of heat transfer and the coolant flow rate. As a result, to improve the solar installation dynamics required is to increase its capacity, which is determined by the amount of solar collectors.

To take into account the consumption mode in the solar installations design we must determine the required SS capacity for each mode. The maximum of these values provides all predefined hot water parsing modes.

The final solar power installations choice is determined on the basis of technical and economic feasibility calculation accounting the full solar installation cost and the operational cost of an additional heat source used.

\section{Література}

1. Дьяков, А.Ф. Эффективное использование местных и возобновляемых энергоресурсов - важная задача улучшения энергоснабжения, повышения энергобезопасности страны и надежный задел энергетики будущего / А.Ф. Дьяков, Э.М. Перминов // Энергетик. — 2014. — № 2. - С. 3 - 9.

2. Laughton, C. Solar Domestic Water Heating: The Earthscan Expert Handbook for Planning, Design and Installation / C. Laughton. - London; Washington: Earthscan, 2010. — 245 p.

3. Atam Kumar. Novel design concepts in solar water heating / Atam Kumar // Proceedings of the Workshop on Solar Water Heating Systems, New Delhi, India 6-10 May, 1985. - Dordrecht, Holland: D.Reidel Publishing Company, 1986. - PP. 337 - 345.

4. Гелиотехника Logasol для горячего водоснабжения и поддержки отопления. Документация для проектирования. Издание: 03/2013. — Buderus, 2013. - 120 с.

5. Книга о «Солнце». Руководство по проектированию систем солнечного теплоснабжения. К 10 летию ООО «Виссманн» в Украине. - К.: Злато-Граф, 2010. - 193 с.

6. Weiss, W.W. Solar Heating Systems for Houses: A Design Handbook for Solar Combisystems / W.W. Weiss. — London: James \& James, 2003. — 313 p.

\section{References}

1. Dyakov, A.F. and Perminov, E.M. (2014). On effective usage of local and renewable resources as an important task of energy supply improvement and energy safety increase, as well as provider of the groundwork for energetics of the future. Energetik, 2, 3-9.

2. Laughton, C. (2010). Solar Domestic Water Heating: The Earthscan Expert Handbook for Planning, Design and Installation. London; Washington: Earthscan.

3. Atam Kumar. (1986). Novel design concepts in solar water heating. In H.P. Garg (Ed.), Proceedings of the Workshop on Solar Water Heating Systems, New Delhi, India 6-10 May, 1985. Dordrecht, Holland: D.Reidel Publishing Company.

4. Buderus (2007). Technical guide - Logasol solar technology for domestic hot water heating and central heating backup -06/2007. Wetzlar, Deutschland: Author.

5. Viessmann Werke (2008). Technical guide. Solar thermal systems. Allendorf (Eder): Author.

6. Weiss, W.W. (2003). Solar Heating Systems for Houses: A Design Handbook for Solar Combisystems. London: James \& James. 